\title{
Synthesis, structure and properties of V(IV) complex with $N^{\prime}$-[(E)-(2,3-dihydroxyphenyl)metylidene]- -2-phenylacetohydrazide
}

\author{
Janusz Szklarzewicz*, Anna Jurowska, Maciej Hodorowicz, Ryszard Gryboś \\ Jagiellonian University, Faculty of Chemistry, Gronostajowa 2, 30-387 Kraków, Poland
}

\section{Article history:}

Received 4 December 2018

Received in revised form

16 March 2019

Accepted 1 April 2019

Available online 2 April 2019

\begin{abstract}
The synthesis and physicochemical properties of new vanadium(IV) complex of formula $[\mathrm{VO}(\mathrm{L})(\mathrm{phen})]$ is described. The L denotes ONO tridentate Schiff base derived from 2,3-dihydroxybenzaldehyde and phenylacetic hydrazide, while phen $=1,10$-phenanthroline used as a co-ligand to stabilize the V(IV) oxidation state. The single crystal X-Ray crystal structure indicates on octahedral geometry of vanadium centre, with 1,10-phenanthroline nitrogen trans to the $\mathrm{V}=\mathrm{O}$ bond. The complex crystalizes in a monoclinic $\mathrm{P} 2_{1 / \mathrm{c}}$ space group, very unusual is that only one isomer is present in the crystal structure. The structure is stabilized by very weak hydrogen bonds and $H \cdot \pi$ and $\pi \cdots \pi$ interactions. The phenyl ring of hydrazide is strongly curved from ONO ligand plane by $70.95^{\circ}$. The spectroscopic characterization (IR, UV-Vis) as well as the cyclic voltammetry measurements are presented and discussed.
\end{abstract}

Keywords: vanadium, complex, Schiff base, structure, 2,3-dihydroxybenzaldehyde, phenylacetic hydrazide

\section{Introduction}

Vanadium(IV) oxido complexes with Schiff bases are one of the most important issues in modern coordination chemistry [1-5]. The interesting properties of these type of compounds are related to the flexibility of the vanadium not only connected with possible geometries (both penta- and hexa-coordinated complexes can be isolated) but also with variety of oxidation states of the metal centre (from +3 to +5 ). In project, presented in this issue, we studied mainly the insulin mimetic properties of such complexes, but also correlation between physicochemical properties (such as structure, oxidation state of vanadium, complex stability, redox potentials etc.) and biological activity. It is worth to note, that the insulin-mimetic properties of vanadium complexes are known from decades [6-10], and several as BMOV or BEOV are used now as standards in diabetes studies investigations [11-15]. What is more, the anticancer, antifungal and antibacterial activities of vanadium complexes are also well recognized [16-18]. In case of vanadium different ligands were investigated in the study of insulin mimetic properties, maltol and its derivatives were found to be especially active $[19,20]$. The main problem is that the bidentate ligands were found to be released in organisms digestion system, resulting also in redox reactions leading to $\mathrm{V}(\mathrm{V})$ or $\mathrm{V}(\mathrm{IV})$ moieties and the role of vanadium complexes could be reduced to activity of simple $\mathrm{VO}^{2+}$

*Corresponding author: szklarze@chemia.uj.edu.pl, tel: 48-12-686-2504, fax: 48-12-686-2750 ions [21]. In last year's Schiff bases were also intensively studied as ligands, as they can be used as models of biological systems [22-24]. This is related not only to the $\mathrm{C}=\mathrm{N}$ bond presence but also to the possibility of utilization many biologically active aldehydes and amines in their synthesis.

In this paper we described the synthesis and physicochemical characterization of vanadium(IV) complex with tridentate ONO hydrazone Schiff base ligand derived from 2,3-dihydroxybenzaldehyde and phenylacetic hydrazide. The use of tridentate ligand makes the complexes much more stable, and in biological activity studies, presented later in this issue, we observe a huge change of biological activity using different ONO ligands indicating that complexes in unchanged (or at least with ONO ligand still coordinated to vanadium) form passes to the cells. The X-ray structure measurement as well as the elemental analysis, magnetic susceptibility, IR, UV-Vis spectra and cyclic voltammetry are presented and indicate the coordination of the oxido, Schiff base and 1,10-phenanthroline ligands to the vanadium(IV) center. The 1,10-phenanthroline was used as a co-ligand to increase the complex stability and to fill the coordination sphere of V(IV).

\section{Materials and Methods}

[VO (acac) $\left.)_{2}\right], 1,10$-phenanthroline (phen), phenylacetic hydrazide and 2,3-dihydroxybenzaldehyde were of analytical grade (Aldrich) and were used as supplied. Ethanol (98\%) of pharmaceutical grade was from Polmos, all other solvents were 
of analytical grade and were used as supplied. $\mathrm{BaSO}_{4}$ was of spectroscopic grade (Japan). $\mathrm{Bu}_{4} \mathrm{NPF}_{6}$ was synthesized from $\mathrm{Bu}_{4} \mathrm{NBr}$ and $\mathrm{KPF}_{6}$ by a standard method [25] and recrystallized from acetone. Microanalysis of carbon, hydrogen and nitrogen were performed using Elementar Vario MICRO Cube elemental analyzer. The electronic absorption spectra were recorded with Shimadzu UV-3600 UV-Vis-NIR spectrophotometer equipped with a CPS-240 temperature controller. Diffuse reflectance spectrum was measured in $\mathrm{BaSO}_{4}$ pellets with $\mathrm{BaSO}_{4}$ as a reference on Shimadzu UV-3600 UV-VIS-NIR equipped with an ISR-240 integrating sphere attachment in 200-3600 nm range. IR spectrum was recorded on a Bruker EQUINOX 55 FT-IR spectrophotometer in $\mathrm{KBr}$ pellets. The magnetic susceptibility measurement was performed on a SHERWOOD SCIENTIFIC magnetic susceptibility balance. Cyclic voltammetry measurements were carried out in DMSO with $\left[\mathrm{Bu}_{4} \mathrm{~N}\right] \mathrm{PF}_{6}(0.1 \mathrm{M})$ as the supporting electrolyte, using Pt working and counter and $\mathrm{Ag}$ / $\mathrm{AgCl}$ as reference electrodes on an AUTOLAB/PGSTAT 128 $\mathrm{N}$ Potentiostat/Galvanostat. $\mathrm{E}_{1 / 2}$ values were calculated from the average anodic and cathodic peak potentials, $\mathrm{E}_{1 / 2}=0.5\left(\mathrm{E}_{\mathrm{a}}+\mathrm{E}_{\mathrm{c}}\right)$. The redox potentials were calibrated versus ferrocene $(0.440 \mathrm{~V}$ versus SHE), which was used as an internal potential standard for measurements in organic solvents to avoid the influence of a liquid junction potential; the final values are reported versus the standard hydrogen electrode (SHE).

\section{Synthesis}

The reaction was carried out in one step. The Schiff base ligand L ( $N^{\prime}$-[(E)-(2,3-dihydroxyphenyl)metylidene]-2-phenylacetohydrazide) was synthesized in situ from 2,3-dihydroxybenzaldehyde and phenylacetic hydrazide in $1: 1$ molar ratio and after completing the reaction vanadyl acetylacetonate was added. The reaction proceeds under anaerobic conditions (Ar) due to the fast oxidation of V(IV) to V(V) in condition used. The addition of phen as a co-ligand results in fast precipitation of the complex by filling the coordination sphere of vanadium and in stabilization of V(IV) oxidation state.

\section{[VO(L)(phen)], 1}

2,3-dihydroxybenzaldehyde (0.207 g, $1.5 \mathrm{mmol})$ and phenylacetic hydrazide $(0.225 \mathrm{~g}, 1.5 \mathrm{mmol})$ in $50 \mathrm{ml}$ of EtOH were refluxed for 14 minutes under Ar yielding a transparent light yellow solution. Then $\left[\mathrm{VO}(\mathrm{acac})_{2}\right](0.398 \mathrm{~g}, 1.5 \mathrm{mmol})$ was added and the mixture was refluxed for 45 minutes giving darkbrown transparent solution. Then phen $(0.271 \mathrm{~g}, 1.5 \mathrm{mmol})$ was added and reflux was continued for 6 minutes. The mixture was left aside for cooling and after 2 hours the black precipitate was filtered off, washed with EtOH and dried in air. Yield $0.464 \mathrm{~g}$. $\mathrm{MW}=515.41$. Calculated for $\mathrm{C}_{27} \mathrm{H}_{20} \mathrm{~N}_{4} \mathrm{O}_{4} \mathrm{~V}: \mathrm{C}, 62.92 ; \mathrm{H}, 3.91 ; \mathrm{N}$, $10.87 \%$. Found: C, 61.88; H, 3.94; N, $10.52 \%$. Magnetic susceptibility measurement, $\mu=1.41 \mu_{\mathrm{B}}$.

\section{Crystallographic data collection and structure refinement}

Diffraction intensity data for single crystal of the compound (1) were collected at room temperature on a KappaCCD (Nonius) diffractometer with graphite-monochromated Mo Ka radiation $(\lambda=0.71073 \AA)$. Cell refinement and data reduction were performed using firmware [26, 27]. Positions of all of non-hydrogen atoms were determined by direct methods using SHELXL-2017/1 [28]. All non-hydrogen atoms were refined anisotropically using weighted full-matrix least-squares on $F^{2}$. Refinement and further calculations were carried out using SHELXL 2017/1 [28]. All hydrogen atoms joined to carbon atoms were positioned with an idealized geometries and refined using a riding model with $U_{\text {iso }}(\mathrm{H})$ fixed at $1.5 U_{\text {eq }}$ of C for methyl groups and $1.2 U_{\text {eq }}$ of $\mathrm{C}$ for other groups. The hydrogen atom of -OH (O8) substituent was found in the difference-Fourier map and refined with an isotropic thermal parameter. The figures were made using DIAMOND software [29]. CCDC 1851403 contains the supplementary crystallographic data for the complex. These data can be obtained free of charge from the Cambridge Crystallographic Data Centre via www.ccdc.cam.ac.uk/ data_request/cif.

\section{Results and Discussion}

The reaction of $\left[\mathrm{VO}(\mathrm{acac})_{2}\right]$ with Schiff base ligand $\mathbf{L}$ ( $N^{\prime}$-[(E)-(2,3-dihydroxyphenyl)metylidene]-2-phenylacetohydrazide), synthesized in situ from 2,3-dihydroxybenzaldehyde and phenylacetic hydrazide in $1: 1$ in EtOH solvent under anaerobic conditions, results in formation of dark brown solution. Addition of phen results in solution colour change to dark red and fast precipitation of complex 1 and stabilization of +4 oxidation state of vanadium. Absence of phen results in sensitivity of complex solution on oxygen and formation of the mixture of the products. The magnetic susceptibility measurement indicates on V(IV) oxidation state in $\mathbf{1}$. Complex is stable in air, soluble in organic solvents and almost insoluble in water.

\section{Crystal structure}

The complex crystallizes in the monoclinic space group $\mathrm{P} 2_{1 / \mathrm{c}}$ with the asymmetric cell unit containing one molecule of [VOL(phen)] complex. The crystallographic data and detailed information on the structure solution and refinement for $\mathbf{1}$ are given in Table 1 while the molecular structure with the atom labelling scheme is illustrated in Fig. 1. The selected bond parameters are summarized in Table 2.

As depicted in Fig. 1 the oxidovanadium cation $\left(\mathrm{VO}^{2+}\right)$ is meridionally coordinated by the $\mathrm{L}^{2-}$ tridentate hydrazone ligand, through the phenolate oxygen (O7), azomethine nitrogen (N10) and enolate oxygen (O13) and facially by bidentate phen ligand $(\mathrm{N} 23, \mathrm{~N} 34)$. The V1 atom presents a slightly distorted O3N3 octa- 
hedral environment with the $\mathrm{O} 7, \mathrm{~N} 10, \mathrm{O} 13$ atoms from the $\mathrm{L}_{\mathrm{ONO}}{ }^{2-}$ ligand and $\mathrm{N} 23$ from the $\mathrm{L}_{\text {phen }}$ molecule defining the equatorial plane. The second nitrogen atom of phen $(\mathrm{N} 34)$ and the $\mathrm{O}_{\text {oxido }}$ (O21) occupy the axial positions (difference between the V1-N34 and V1-O21 is $0.743 \AA$ ). The L ligand of the complex appears to be strongly twisted which is noticeable on the basis of the value of the dihedral angle between dihydroxyphenyl and phenyl rings $\left(70.95^{\circ}\right)$. The presented structure of $\mathbf{1}$ is the first vanadium complex listed in the literature, with phenylacetic hydrazide or with Schiff bases with this component, thus it is difficult to compare the bond lengths and angles with similar complexes. In literature the complexes with copper, silver, nickel and manganese are known, in most cases they are not monomers [30-34]. For ligand $\mathrm{L}$ dihedral angle between dihydroxyphenyl and phenyl rings is $81.71^{\circ}$. For monomeric complexes it can be smaller; $70.81^{\circ}$ for square planar copper [30], 78.23 ${ }^{\circ}$ for octahedral copper [30] and bigger as for silver complex $85.38^{\circ}$ [33]. For polymeric complexes the lowest angle was found for hexameric manganese complex $-68.80^{\circ}$ [34], for trimeric $\mathrm{Ni}(\mathrm{II})$ complex $-80.84^{\circ}$ [31] and for dimeric complexes vary between 71.94 to $89.32^{\circ}$ [30].

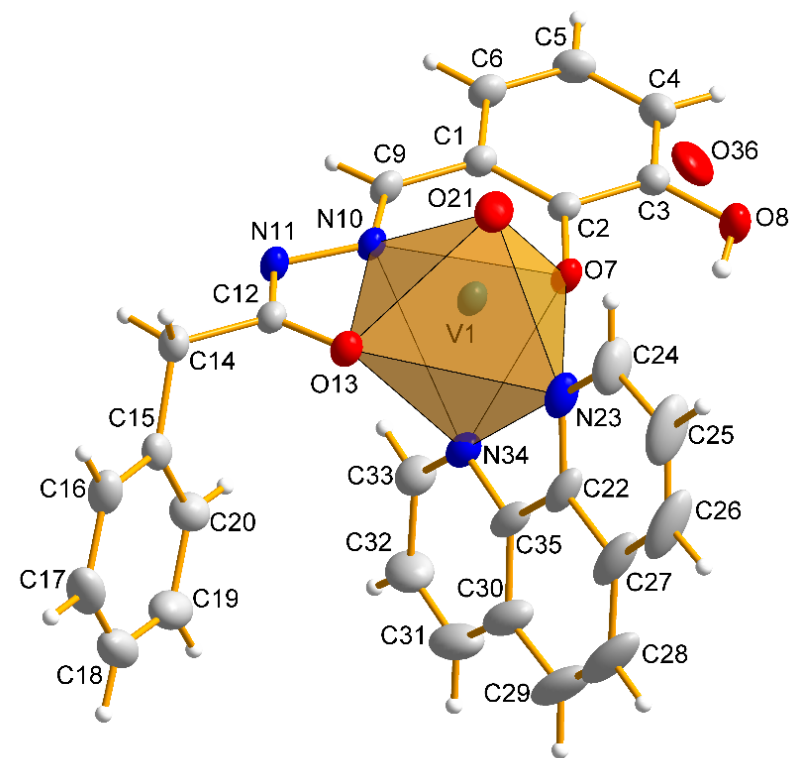

Figure 1. The asymmetric part of the unit cell of the complex 1 with adopted atomic numbering scheme. All non-hydrogen atoms are represented at 30\% probability thermal ellipsoids

Table 1. Crystal data and structure refinement for $\mathbf{1}$

\begin{tabular}{|c|c|}
\hline Empirical formula & $\mathrm{C}_{27} \mathrm{H}_{20} \mathrm{~N}_{4} \mathrm{O}_{4.25} \mathrm{~V}$ \\
\hline Formula weight & 519.41 \\
\hline Temperature & 293(2) K \\
\hline Wavelength & $0.71073 \AA$ \\
\hline Crystal system & monoclinic \\
\hline Space group & $\mathrm{P} 2_{1} / \mathrm{c}$ \\
\hline \multirow[t]{3}{*}{ Unit cell dimensions } & $\mathrm{a}=10.2890(3) \AA \quad \alpha=90^{\circ}$ \\
\hline & $\mathrm{b}=16.0410(5) \AA \quad \beta=97.106(2)^{\circ}$ \\
\hline & $\mathrm{c}=14.3930(4) \AA \quad \gamma=90^{\circ}$ \\
\hline Volume & $2357.26(12) \AA^{3}$ \\
\hline Z & 1 \\
\hline Density (calculated) & $1.464 \mathrm{Mg} / \mathrm{m}^{3}$ \\
\hline Absorption coefficient & $0.465 \mathrm{~mm}^{-1}$ \\
\hline $\mathrm{F}(000)$ & 1068 \\
\hline Crystal size & $\begin{array}{l}0.150 \times 0.140 \times \\
0.050 \mathrm{~mm}^{3}\end{array}$ \\
\hline Theta range for data collection & 2.913 to $27.504^{\circ}$ \\
\hline Index ranges & $-13 \leq \mathrm{h}<=13,-20 \leq \mathrm{k} \leq 20,-18 \leq \mathrm{l} \leq 18$ \\
\hline Reflections collected & 19452 \\
\hline Independent reflections & $5393[\mathrm{R}(\mathrm{int})=0.0475]$ \\
\hline Completeness to theta $=25.242^{\circ}$ & $99.7 \%$ \\
\hline Refinement method & Full-matrix least-squares on $\mathrm{F}^{2}$ \\
\hline Data / restraints / parameters & $5393 / 0 / 338$ \\
\hline Goodness-of-fit on $\mathrm{F}^{2}$ & 1.070 \\
\hline Final $R$ indices $[\mathrm{I}>2 \operatorname{sigma}(\mathrm{I})]$ & $\mathrm{R} 1=0.0486, \mathrm{wR} 2=0.1059$ \\
\hline $\mathrm{R}$ indices (all data) & $\mathrm{R} 1=0.0759, \mathrm{wR} 2=0.1175$ \\
\hline Largest diff. peak and hole & 0.449 and -0.346 e..$\AA^{-3}$ \\
\hline
\end{tabular}


Table 2. Selected bond lengths $[\AA]$ and bond angles $\left[^{\circ}\right]$ in 1

\begin{tabular}{|c|c|c|c|}
\hline \multicolumn{4}{|l|}{ Bond lengths } \\
\hline $\mathrm{V}(1)-\mathrm{O}(21)$ & $1.5983(19)$ & $\mathrm{C}(15)-\mathrm{C}(16)$ & $1.384(4)$ \\
\hline $\mathrm{V}(1)-\mathrm{O}(7)$ & $1.9452(16)$ & $\mathrm{C}(16)-\mathrm{C}(17)$ & $1.396(4)$ \\
\hline $\mathrm{V}(1)-\mathrm{O}(13)$ & $2.0145(16)$ & $\mathrm{C}(17)-\mathrm{C}(18)$ & $1.361(5)$ \\
\hline $\mathrm{V}(1)-\mathrm{N}(10)$ & $2.0517(18)$ & C(18)-C(19) & $1.370(5)$ \\
\hline $\mathrm{V}(1)-\mathrm{N}(23)$ & $2.149(2)$ & $C(19)-C(20)$ & $1.387(4)$ \\
\hline $\mathrm{V}(1)-\mathrm{N}(34)$ & $2.341(2)$ & $\mathrm{C}(22)-\mathrm{N}(23)$ & $1.356(4)$ \\
\hline $\mathrm{C}(1)-\mathrm{C}(2)$ & $1.412(3)$ & $\mathrm{C}(22)-\mathrm{C}(27)$ & $1.414(4)$ \\
\hline$C(1)-C(6)$ & $1.413(3)$ & $C(22)-C(35)$ & $1.419(4)$ \\
\hline $\mathrm{C}(1)-\mathrm{C}(9)$ & $1.434(3)$ & $\mathrm{N}(23)-\mathrm{C}(24)$ & $1.329(4)$ \\
\hline $\mathrm{C}(2)-\mathrm{O}(7)$ & $1.323(3)$ & $C(24)-C(25)$ & $1.405(5)$ \\
\hline$C(2)-C(3)$ & $1.411(3)$ & $C(25)-C(26)$ & $1.345(6)$ \\
\hline $\mathrm{C}(3)-\mathrm{O}(8)$ & $1.361(3)$ & $C(26)-C(27)$ & $1.406(6)$ \\
\hline$C(3)-C(4)$ & $1.376(3)$ & $\mathrm{C}(27)-\mathrm{C}(28)$ & $1.431(6)$ \\
\hline$C(4)-C(5)$ & $1.390(4)$ & $\mathrm{C}(28)-\mathrm{C}(29)$ & $1.328(6)$ \\
\hline$C(5)-C(6)$ & $1.363(4)$ & $\mathrm{C}(29)-\mathrm{C}(30)$ & $1.435(5)$ \\
\hline $\mathrm{C}(9)-\mathrm{N}(10)$ & $1.289(3)$ & $C(30)-C(31)$ & $1.386(5)$ \\
\hline $\mathrm{N}(10)-\mathrm{N}(11)$ & $1.414(3)$ & $\mathrm{C}(30)-\mathrm{C}(35)$ & $1.410(4)$ \\
\hline $\mathrm{N}(11)-\mathrm{C}(12)$ & $1.301(3)$ & $\mathrm{C}(31)-\mathrm{C}(32)$ & $1.370(5)$ \\
\hline $\mathrm{C}(12)-\mathrm{O}(13)$ & $1.299(3)$ & $\mathrm{C}(32)-\mathrm{C}(33)$ & $1.403(4)$ \\
\hline $\mathrm{C}(12)-\mathrm{C}(14)$ & $1.500(3)$ & $\mathrm{C}(33)-\mathrm{N}(34)$ & $1.323(3)$ \\
\hline $\mathrm{C}(14)-\mathrm{C}(15)$ & $1.516(3)$ & $\mathrm{N}(34)-\mathrm{C}(35)$ & $1.360(3)$ \\
\hline $\mathrm{C}(15)-\mathrm{C}(20)$ & $1.381(4)$ & & \\
\hline \multicolumn{4}{|l|}{ Bond angles } \\
\hline $\mathrm{O}(21)-\mathrm{V}(1)-\mathrm{O}(7)$ & $102.09(9)$ & $\mathrm{O}(13)-\mathrm{V}(1)-\mathrm{N}(23)$ & $95.49(7)$ \\
\hline $\mathrm{O}(21)-\mathrm{V}(1)-\mathrm{O}(13$ & $101.27(9)$ & $\mathrm{N}(10)-\mathrm{V}(1)-\mathrm{N}(23)$ & $163.14(9)$ \\
\hline $\mathrm{O}(7)-\mathrm{V}(1)-\mathrm{O}(13)$ & $153.93(7)$ & $\mathrm{O}(21)-\mathrm{V}(1)-\mathrm{N}(34)$ & $164.14(9)$ \\
\hline $\mathrm{O}(21)-\mathrm{V}(1)-\mathrm{N}(10$ & $104.41(9)$ & $\mathrm{O}(7)-\mathrm{V}(1)-\mathrm{N}(34)$ & $81.95(7)$ \\
\hline $\mathrm{O}(7)-\mathrm{V}(1)-\mathrm{N}(10)$ & $86.58(7)$ & $\mathrm{O}(13)-\mathrm{V}(1)-\mathrm{N}(34)$ & $78.72(7)$ \\
\hline $\mathrm{O}(13)-\mathrm{V}(1)-\mathrm{N}(10$ & $76.51(7)$ & $\mathrm{N}(10)-\mathrm{V}(1)-\mathrm{N}(34)$ & $91.07(7)$ \\
\hline $\mathrm{O}(21)-\mathrm{V}(1)-\mathrm{N}(23$ & $91.62(10$ & $\mathrm{N}(23)-\mathrm{V}(1)-\mathrm{N}(34)$ & $72.66(8)$ \\
\hline $\mathrm{O}(7)-\mathrm{V}(1)-\mathrm{N}(23)$ & $95.26(7)$ & & \\
\hline
\end{tabular}

The packing scheme, shown in Fig. 2, indicates the zig-zag type of complex arrangement with the aromatic rings forming an s shape chains. Packing reveals that the complex molecules are stabilized by three types of hydrogen bonds and additionally by two types of $\mathrm{C}-\mathrm{H} \cdots \pi$ and two $\pi \cdots \pi$ interactions which are they are very weak. The interesting is the bifurcated hydrogen bond between $\mathrm{O} 7, \mathrm{O} 8$ and $\mathrm{N} 11$. All these interactions are responsible for self-assembly of the complex molecules in layers (Fig. 2) and stabilization of the 3D structure. In the vanadium complex, studied earlier, the mixture of isomers with the different

Table 3. Hydrogen bonds for $\mathbf{1}\left[\AA\right.$ and $\left.^{\circ}\right]$

\begin{tabular}{lllll}
\hline $\mathrm{D}-\mathrm{H} \ldots \mathrm{A}$ & $\mathrm{d}(\mathrm{D}-\mathrm{H})$ & $\mathrm{d}(\mathrm{H} \ldots \mathrm{A})$ & $\mathrm{d}(\mathrm{D} \ldots \mathrm{A})$ & $<(\mathrm{DHA})$ \\
\hline $\mathrm{C}(24)-\mathrm{H}(24) \ldots \mathrm{O}(21)$ & 0.93 & 2.48 & $2.944(4)$ & 110.8 \\
$\mathrm{O}(8)-\mathrm{H}(8) \ldots \mathrm{O}(7)$ & $0.77(3)$ & $2.25(3)$ & $2.663(2)$ & $114(3)$ \\
$\mathrm{O}(8)-\mathrm{H}(8) \ldots \mathrm{N}(11)^{1}$ & $0.77(3)$ & $2.26(4)$ & $2.914(3)$ & $143(3)$ \\
\hline
\end{tabular}

Symmetry transformations used to generate equivalent atoms: ${ }^{1} x,-y+1 / 2, z+1 / 2$

summarized in Tables 3, 4 and 5. Fig. 3 and 4 show the $\pi$ interactions in $\mathbf{1}$. The hydrogen bond distances are relatively short, but the $<($ DHA $)$ angle is much lower than $180^{\circ}$ indicating that position of 5- and 6-membered ring of ONO ligand versus phen ligand was observed [35]. In 1 rather unusual case of only one isomer presence in cell unit is observed. 


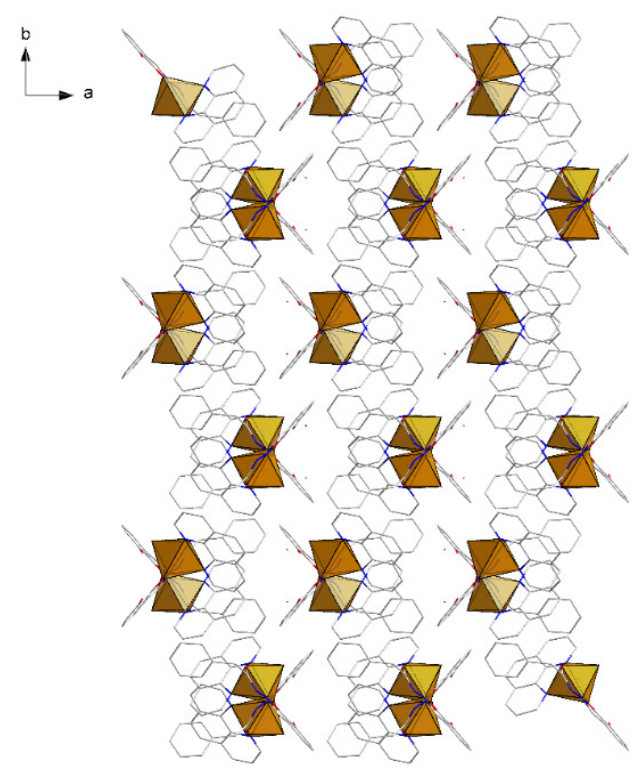

Figure 2. The crystal packing in $\mathbf{1}$ through [001] direction

Table 4. $\pi \ldots \pi$ interactions in $\mathbf{1}$

\begin{tabular}{lll}
\hline & $\pi \ldots \pi$ & shift \\
\hline $\operatorname{Cg}(1) \ldots \operatorname{Cg}(2)[2-X,-Y, 1-Z]$ & $3.683(2)$ & 1.108 \\
$\operatorname{Cg}(2) \ldots \operatorname{Cg}(1)[2-X,-Y, 1-Z]$ & $3.682(2)$ & 1.168 \\
\hline
\end{tabular}

Cg(1): N(23)-C(22)-C(27)-C(26)-C(25)-C(24),

Cg(2): C(22)-C(27)-C(28)-C(29)-C(30)-C(35)

Table 5. C-H... $\pi$ interactions in $\mathbf{1}$

\begin{tabular}{lcll}
\hline & H...Cg & X-H...Cg & X...Cg \\
\hline $\mathrm{C}(17)-\mathrm{H}(17) \ldots \mathrm{Cg}(3)[2-\mathrm{X},-1 / 2+\mathrm{Y}, 1 / 2-\mathrm{Z}]$ & 2.81 & 145 & $3.607(4)$ \\
$\mathrm{C}(26)-\mathrm{H}(26) \ldots \mathrm{Cg}(4)[2-\mathrm{X},-\mathrm{Y}, 1-\mathrm{Z}]$ & 2.88 & 132 & $3.574(4)$ \\
\hline
\end{tabular}

Cg(3): C(1)-C(2)-C(3)-C(4)-C(5)-C(6),

Cg(4): C(15)-C(16)-C(17)-C(18)-C(19)-C(20)

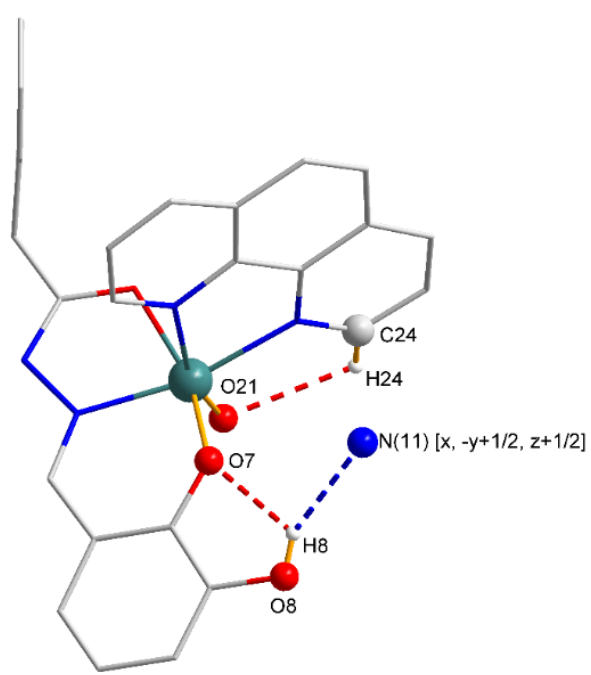

Figure 3. The 3D supramolecular network of 1 formed through hydrogen bonds. $\mathrm{H}$-atoms (without $\mathrm{H} 24$ and $\mathrm{H} 8$ ) are omitted for clarity

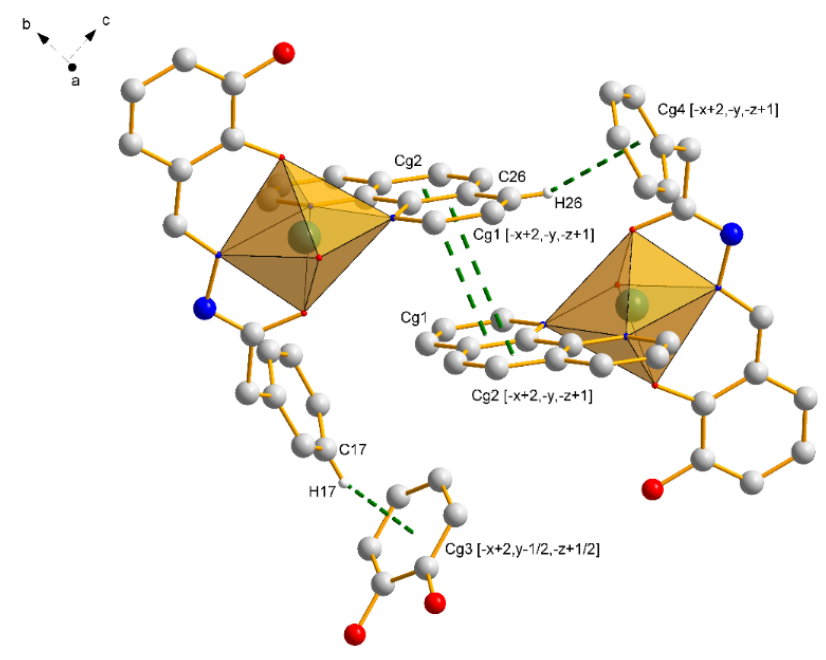

Figure 4. The 3D supramolecular network of 1 formed through hydrogen bonds. H-atoms (without $\mathrm{H} 17$ and $\mathrm{H} 26$ ) are omitted for clarity

\section{Spectral data}

The IR spectrum of 1 in $\mathrm{KBr}$ (in $400-4000 \mathrm{~cm}^{-1}$ ) is presented in Fig. 5. The most important is the very strong band at $962 \mathrm{~cm}^{-1}$, typical for V(IV) complexes [36, 37]. The band at $1610 \mathrm{~cm}^{-1} \mathrm{can}$ be attributed to imino $\mathrm{C}=\mathrm{N}$ bond typical for Schiff bases and characteristic bands for phen at 725, 1424 and $1515 \mathrm{~cm}^{-1}$ [38]. In other region the bands of Schiff base ligand components are observed. The absence of bands of solvent molecules confirms the complex composition.

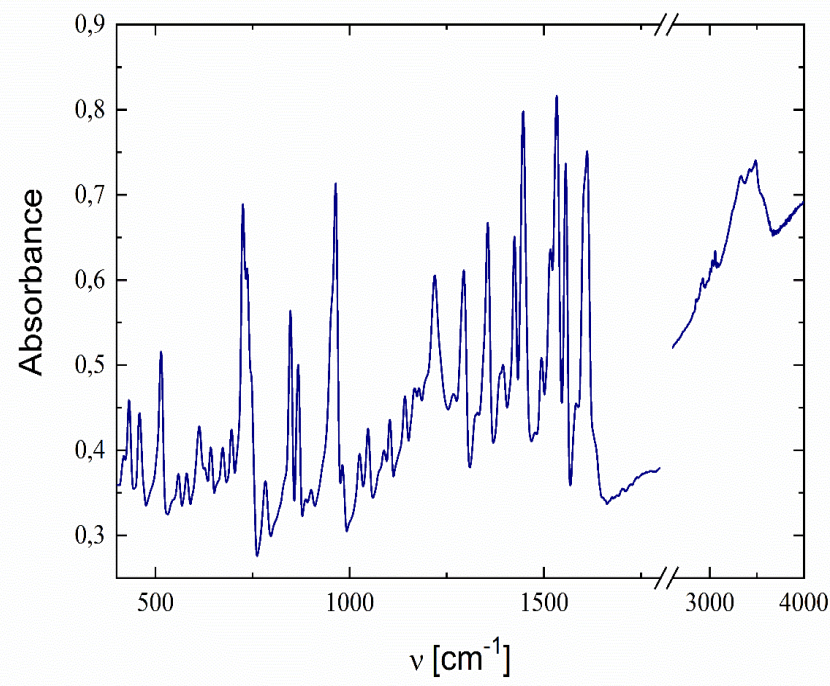

Figure 5. The IR spectrum of $\mathbf{1}$ in $\mathrm{KBr}$.

The UV-Vis solution spectra were measured in $200-900 \mathrm{~nm}$ range and are presented in Fig. 6. The bands in UV part are a superposition of the phen and L ligands while that above 400 $\mathrm{nm}$ to metal-to-ligand charge-transfer (MLCT) connected with Schiff base ligand (L). The MLCT character of the band at $c a$. $410 \mathrm{~nm}$ is confirmed by its solvatochromism, shown in Fig. 6. In 
DMF and DMSO due to the solvent cut-off range, bands below $315 \mathrm{~nm}$ cannot be observed.

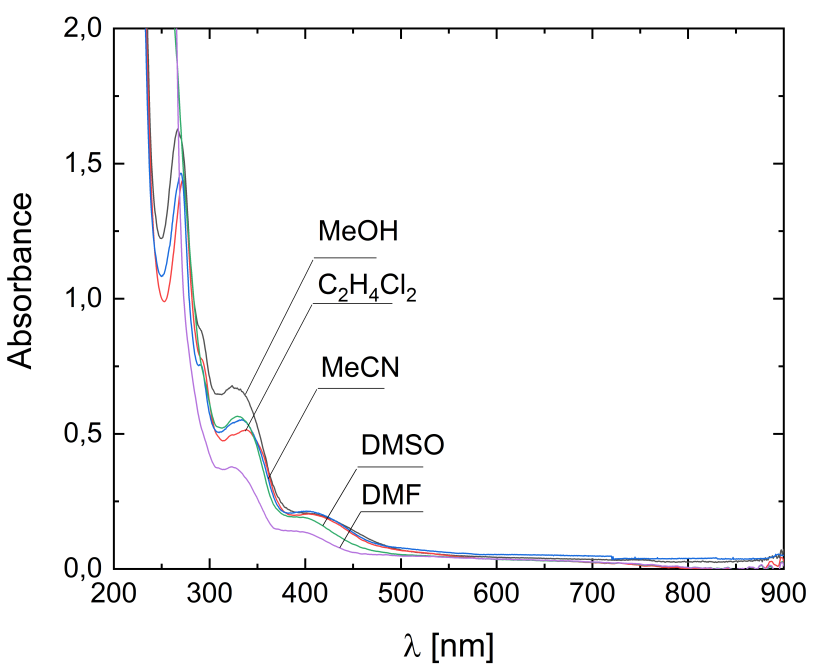

Figure 6. The electronic spectra of $\mathbf{1}$ in different solvents, $\mathrm{d}=1 \mathrm{~cm}$

The molar absorption coefficients in DMSO are 2.91.10 $\mathrm{dm}^{3} \mathrm{M}^{-1} \mathrm{~cm}^{-1}$ (for $394 \mathrm{~nm}$ band) and $9.6 \cdot 10^{3} \mathrm{dm}^{3} \mathrm{M}^{-1} \mathrm{~cm}^{-1}$ (for $329 \mathrm{~nm}$ band). The intensity of these bands indicates on their charge-transfer (CT) character. Due to low solubility of the complex in the studied solvent, $d-d$ transitions are not observed in solution. The more interesting is the reflection spectrum, presented in Fig. 7 after Kubelka-Munk transformation, where band at $851 \mathrm{~cm}^{-1}$ and shoulder at ca. $722 \mathrm{~nm}$ are observed. These bands can be attributed to $d-d$ transitions of V(IV), the presence of two bands can be induced by the distortion of octahedron, typical attributed to the Jahn-Teller effect of $d^{l}$ configuration of V(IV). In the UV part the bands attributed to phen and Schiff base ligands (at 228, 275 and $348 \mathrm{~nm}$ ) are observed. The bands at 424 and $521 \mathrm{~nm}$ can be attributed to CT transitions of L and phen ligand respectively. The solutions of $\mathbf{1}$ in organic solvents were found to be relatively stable in time, and after several hours only small changes in spectra can be detected.

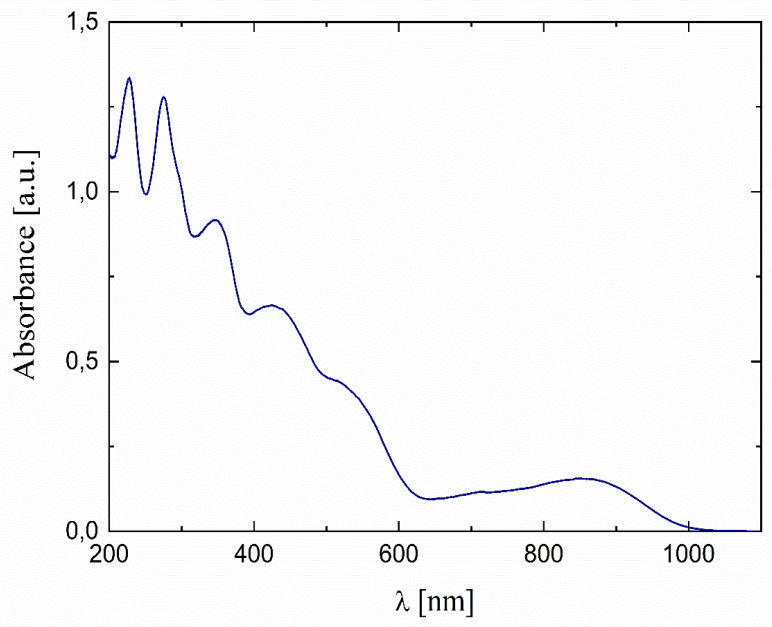

Figure 7. The reflection spectrum of 1 after Kubelka-Munk transformation

\section{Cyclic voltammetry measurements}

The cyclic voltammetry measurements results of $\mathbf{1}$ in DMSO are presented in Fig. 8. Pt working and counting, $\mathrm{Ag} / \mathrm{AgCl}$ as a reference electrode, $0.1 \mathrm{M} \mathrm{Bu}_{4} \mathrm{NPF}_{6}$ as electrolyte were used. The irreversible oxidation peak at $0.589 \mathrm{~V}$ can be attributed to $\mathrm{V}(\mathrm{IV} / \mathrm{V})$ redox couple. The peak position is almost independent on scan speed, as shown in inset of the Fig. 8. Such a behavior is rather typical for reversible redox couple, the lack of reduction peak can be interpreted as chemical reduction following the oxidation process. The presence of two reduction peaks at $-0.208 \mathrm{~V}$ and $-6.00 \mathrm{~V}$ is in agreement with this observation and these peaks can be attributed to reduction of side products of $\mathrm{V}(\mathrm{V})$ chemical reduction and they are not observed when scan range is reduced (see middle inset in Fig. 8). The reversible process at $\mathrm{E}_{1 / 2}$ $=-1.39 \mathrm{~V}$ with $\Delta \mathrm{E}=108 \mathrm{mV}$ at $100 \mathrm{mV} \cdot \mathrm{s}^{-1}$ is attributed to phen ligand reduction ( phen $+\mathrm{e}^{-}=$phen-).

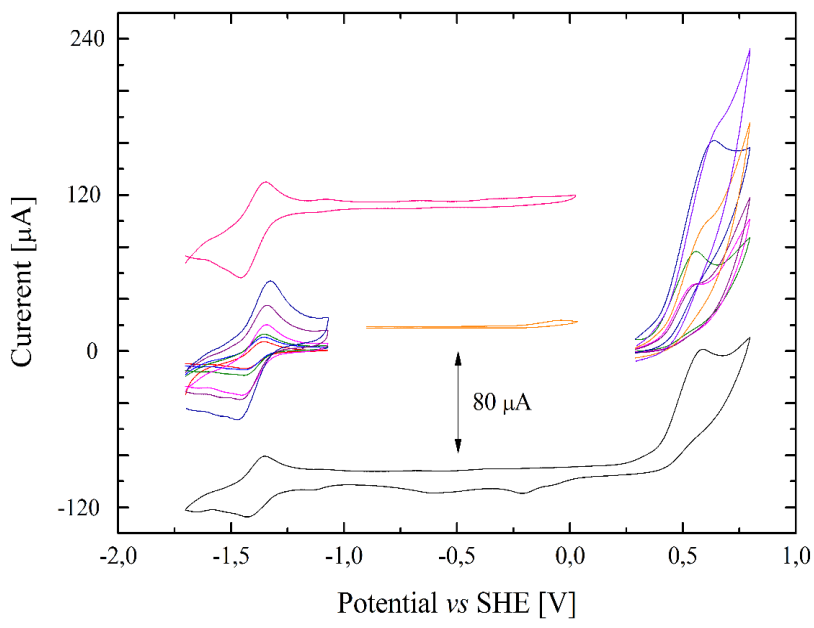

Figure 8. The cyclic voltammetry measurements of $\mathbf{1}$ in DMSO. Pt working and counting, $\mathrm{Ag} / \mathrm{AgCl}$ as a reference electrode, $0.1 \mathrm{M} \mathrm{Bu}_{4} \mathrm{NPF}_{6}$ as electrolyte. Scan speed $100 \mathrm{mV} \cdot \mathrm{s}^{-1}$. Insets, scan speed $100 \mathrm{mV} \cdot \mathrm{s}^{-1}$, for measurements at different scan speeds it vary from 20 to $250 \mathrm{mV} \cdot \mathrm{s}^{-1}$

\section{Conclusions}

The new complex of V(IV) with ONO tridentate, oxido and phen ligands was isolated and described. It was found to be promising for future investigation of its biological activity, due to its stability in solid state and in solvent studied. The addition of phen results in stabilization of +4 oxidation state of vanadium. The $\mathrm{X}$-ray crystal structure shows, that only one isomer is present in the unit cell. The question which still requires further investigations is if this is the only product of the synthetic procedure or $\mathbf{1}$ is a mixture of isomers, but only one of them was chosen for measurements. We could not distinguish this basing on other measurements till now. The cyclic voltammetry shows, that $\mathrm{V}(\mathrm{IV})$ can be relatively easy oxidized to $\mathrm{V}(\mathrm{V})$, but this induces chemical reactions. Such a behavior may be very important for biological activity of $\mathbf{1}$ as insulin mimetic compound. 


\section{Acknowledgments}

This work was partly financed by the European Regional Development Fund under the Innovative Economy Programme 2007-2013 (WND POIG.01.03.01-174/09). The complexes are protected by the patent P.401493.

\section{References}

1. Mukherjee T, Costa Pessoa J, Kumar A, Sarkar AR. Oxidovanadium (IV) Schiff base complex derived from vitamin B6: synthesis, characterization, and insulin enhancing properties. Inorganic Chemistry. 2011; 50:4349-4361.

2. Holder AA, Taylor P, Magnusen AR, Moffett ET, Meyer K, Hong Y, Ramsdale SE, Gordon M, Stubbs J, Seymour LA, Acharya D, Weber RT, Smith PF, Dismukes GC, Ji P, Menocal L, Bai F, Williams JL, Cropek DM, Jarrett WL. Preliminary anti-cancer photodynamic therapeutic in vitro studies with mixed-metal binuclear ruthenium (II)-vanadium (IV) complexes. Dalton Transactions. 2013; 42:11881-11899.

3. León IE, Parajón-Costa BS, Franca CA, Etcheverry SB, Baran EJ. A New Oxidovanadium (IV) Complex of Oxodiacetic Acid and dppz: Spectroscopic and DFT Study. Antitumor Action on MG-63 Human Osteosarcoma Cell Line. Biological Trace Element Research. 2015; 164:198-204.

4. Abaszadeh M, Seifi M, Ebrahimipour SY. Two ligand oxidio-vanadium (IV) complexes as novel efficient catalysts in multicomponent reactions for synthesis of tetrahydrobenzopyran derivatives. Bulletin of the Chemical Society of Ethiopia. 2016; 30:253-262.

5. Bikas R, Shahmoradi E, Noshiranzadeh N, Emami M, Reinoso $\mathrm{S}$. The effects of halogen substituents on the catalytic oxidation of benzyl-alcohols in the presence of dinuclear oxidovanadium (IV) complex. Inorganica Chimica Acta. 2017; 466:100-109.

6. Sakurai H, Fujii K, Watanabe H, Tamura H. Orally active and long-term acting insulin-mimetic vanadyl complex: bis (picolinato) oxovanadium (IV). Biochemical and Biophysical Research Communications. 1995; 214:1095-1101.

7. Melchior M, Thompson KH, Jong JM, Rettig SJ, Shuter E, Yuen VG, Zhou Y, McNeill JH, Orvig C. Vanadium complexes as insulin mimetic agents: coordination chemistry and in vivo studies of oxovanadium (IV) and dioxovanadate (V) complexes formed from naturally occurring chelating oxazolinate, thiazolinate, or picolinate units. Inorganic Chemistry. 1999; 38:2288-2293.

8. Rehder D, Pessoa JC, Geraldes CF, Castro MM, Kabanos T, Kiss T, Meier B, Micera G, Pettersson L, Rangel M, Salifoglou A, Turel I, Wang D. In vitro study of the insulin-mimetic behaviour of vanadium (IV, V) coordination compounds. JBIC Journal of Biological Inorganic Chemistry. 2002; 7:384396.
9. Halevas E, Tsave O, Yavropoulou MP, Hatzidimitriou A, Yovos JG, Psycharis V, Gabriel C, Salifoglou A. Design, synthesis and characterization of novel binary V(V)-Schiff base materials linked with insulin-mimetic vanadium-induced differentiation of 3T3-L1 fibroblasts to adipocytes. Structure-function correlations at the molecular level. Journal of Inorganic Biochemistry. 2015; 147:99-115.

10. Li SY, Zhai WQ, Li ZW, Li A, Jiang YM, Li W. Synthesis, Crystal Structures and Insulin-Enhancing Activity of Vanadium (V) Complexes with Hydrazone Ligands. Russian Journal of Coordination Chemistry. 2018; 44:701-706.

11. Yuen VG, Orvig C, McNeill JH. Glucose-lowering effects of a new organic vanadium complex, bis (maltolato) oxovanadium (IV). Canadian Journal of Physiology and Pharmacology. 1993; 71:263-269.

12. Cong XQ, Piao MH, Li Y, Xie L, Liu Y. Bis (maltolato) oxovanadium (IV)(BMOV) attenuates apoptosis in high glucose-treated cardiac cells and diabetic rat hearts by regulating the unfolded protein responses (UPRs). Biological Trace Element Research. 2016; 173:390-398.

13. Wang J, Yuen VG, McNeill JH. Effect of vanadium on insulin and leptin in Zucker diabetic fatty rats. Molecular and Cellular Biochemistry. 2001; 218:93-96.

14. Facchini DM, Yuen VG, Battell ML, McNeill JH, Grynpas MD. The effects of vanadium treatment on bone in diabetic and non-diabetic rats. Bone. 2016; 38:368-377.

15. Jakusch T, Kiss T. In vitro study of the antidiabetic behavior of vanadium compounds. Coordination Chemistry Reviews. 2017; 351:118-126.

16. Patra D, Paul S, Sepay N, Kundu R, Ghosh T. Structure-activity relationship on DNA binding and anticancer activities of a family of mixed-ligand oxidovanadium (V) hydrazone complexes. Journal of Biomolecular Structure and Dynamics. 2017; 13:1-13.

17. Torabi S, Mohammadi M, Shirvani M. Antidiabetic, Antioxidant, Antibacterial, and Antifungal Activities of Vanadyl Schiff Base Complexes. Trends in Pharmaceutical Sciences. 2018; 4:87-94.

18. Farzanfar J, Ghasemi K, Rezvani AR, Delarami HS, Ebrahimi A, Hosseinpoor H, Eskandari A, Rudbari HA, Bruno G. Synthesis, characterization, X-ray crystal structure, DFT calculation and antibacterial activities of new vanadium (IV, V) complexes containing chelidamic acid and novel thiourea derivatives. Journal of Inorganic Biochemistry. 2015; 147:54-64.

19. Chen XF, Wang TR, Ma Z, Yu Y, Tang L, Jin LY, Sheng GH, Zhu HL. Synthesis, crystal structures and insulin-like activity of two new oxidovanadium (V) complexes with aroylhydrazones and maltol mixed-ligands. Polyhedron. 2017; 137:321-324.

20. Zhao X, Chen X, Li J, Chen J, Sheng G, Niu F, Qu D, Huo Y, Zhu H, You Z. Synthesis, structures and insulin-like activity of oxidovanadium (V) complexes with aroylhydrazones and ethylmaltol mixed-ligands. Polyhedron. 2015; 97:268-272. 
21. Thompson, K.H., Lichter J, LeBel K, Scaife MC, McNeill JH, Orvig C, Vanadium treatment of type 2 diabetes: A view to the future. Journal of Inorganic Biochemistry. 2009; 103:554558

22. Prakash A, Adhikari D. Application of Schiff bases and their metal complexes-A Review. International Journal of ChemTech Research. 2011; 3:1891-1896.

23. Zaheer M, Shah A, Akhter Z, Qureshi R, Mirza B, Tauseef M, Bolte M. Synthesis, characterization, electrochemistry and evaluation of biological activities of some ferrocenyl Schiff bases. Applied Organometallic Chemistry. 2011; 25:61-69.

24. Hranjec M, Starčević K, Pavelić SK, Lučin P, Pavelić K, Zamola GK. Synthesis, spectroscopic characterization and antiproliferative evaluation in vitro of novel Schiff bases related to benzimidazoles. European Journal of Medicinal Chemistry. 2011; 46:2274-2279.

25. Dümmling S, Eichhorn E, Schneider S, Speiser B, Würde M. Recycling of the Supporting Electrolyte Tetra(n-butyl)ammonium Hexafluorophosphate from Used Electrolyte Solutions. Current Separations. 1996; 5:53-56.

26. Nonius COLLECT. Nonius BV, Delft, The Netherlands; 1998.

27. Otwinowski Z, Minor W., Processing of X-ray diffraction data collected in oscillation mode. Methods in Enzymology, Vol. 276, Macromolecular Crystallography, Part A, edited by Carter Jr CW, Sweet RM, New York: Academic Press; 1997. p. 307-326.

28. Sheldrick GM. Crystal structure refinement with SHELXL. Acta Crystallographica C Structural Chemistry. 2015; 71:3-8.

29. Brandenburg K, Putz H. DIAMOND. Crystal Impact GbR, Bonn, Germany; 2015.

30. Repich HH, Orysyk SI, Orysyk VV, Zborovskii YL, Melnyk AK, Trachevskyi VV, Pekhnyo VI, Vovk MV. Influence of synthesis conditions on complexation of $\mathrm{Cu}$ (II) with $\mathrm{O}, \mathrm{N}, \mathrm{O}$ tridentate hydrazone ligand. X-ray diffraction and spectroscopic investigations. Journal of Molecular Structure. 2017; 1146:222- 232
31. Luo W, Meng X-G, Xiang J-F, Duan Y, Cheng G-Z, Ji Z-P. Synthesis, characterization and bioactivity of four novel trinuclear copper(II) and nickel(II) complexes with pentadentate ligands derived from $\mathrm{N}$-acylsalicylhydrazide. Inorganica Chimica Acta. 2008; 361:2667-2676.

32. Wilde F, Lemmerhirt H, Emmrich T, Bednarski PJ, Link A. Microwave-assisted synthesis and evaluation of acylhydrazones as potential inhibitors of bovine glutathione peroxidase. Molecular Diversity. 2014; 18:307-322.

33. Repich HH, Orysyk SI, Orysyk VV, Zborovskii YL, Pekhnyo VI, Vovk MV. Synthesis, crystal structure and spectral characterization of the first $\mathrm{Ag}^{+}$complex compounds involving $\mathrm{O}, \mathrm{N}, \mathrm{O}$-coordinated $\mathrm{N}$-acylhydrazones of salicylaldehyde. Journal of Molecular Structure. 2017; 1144:225-236.

34. Luo W, Wang XT, Meng X-G, Cheng G-Z, Ji Z-P. Metal coordination architectures of $\mathrm{N}$-acyl-salicylhydrazides: The effect of metal ions and steric repulsion of ligands to their structures of polynuclear metal complexes. Polyhedron. 2009; 28:300306.

35. Gryboś R, Szklarzewicz J, Jurowska A, Hodorowicz M. Properties, structure and stability of V(IV) hydrazide Schiff base ligand complex. Journal of Molecular Structure. 2018; 1171:880-887.

36. Mathew M, Carty AJ, Palenik GJ. An Unusual Complex Containing Bridging Vanadyl Groups. The Crystal Structure of N,N'-Propylenebis(salicylaldiminato)oxovanadium(IV). Journal of the American Chemical Society. 1970; 92:3197-3198.

37. Cashin B, Cunningham D, Daly P, McArdle P, Munroe M, Ní Chonchubhair N. Donor properties of the vanadyl ion: Reactions of vanadyl salicylaldimine $\beta$-ketimine and acetylacetonato complexes with groups 14 and 15 Lewis acids. Inorganic Chemistry. 2002; 41:773-782.

38. Schilt A, Taylor RC. Infra-red spectra of 1,10-phenanthroline metal complexes in the rock salt region below $2000 \mathrm{~cm}^{-1}$. Journal of Inorganic and Nuclear Chemistry. 1959; 9:211-221. 